\title{
Subjetividades femeninas: de la mímica subversiva a los discursos contestatarios
}

\author{
Lucía Guerra-Cunnigham \\ Universidad de California, Irvine \\ lcumming@uci.edu
}

\author{
¿Qué es la verdad para la mujer?. . \\ Su gran arte es la mentira \\ y su mayor preocupación está en la mera apariencia \\ $y$ en el cultivo de la belleza \\ Friedrich Nietszche
}

A mediados del siglo XIX, la figura de "la mujer ideal" semejaba una amplia campana bajo una cintura breve, pechos abultados y una larga cabellera llena de rizos o en un complicado moño. El corsé usado desde el siglo XVI era un artefacto de género y varillas metálicas que se ceñían al cuerpo para realzar las caderas y el busto (signos de la maternidad) achicando la cintura alrededor de diez centímetros con el objetivo de crear lo que en aquella época se llamaba "una cintura de avispa". Los vestidos debían cubrir hasta la punta de los pies y requerían entre siete y diez metros de tela que en la falda se extendía en forma perfectamente redondeada, gracias a las enaguas confeccionadas con aros de acero en un armado metálico.

El peso de los vestidos, de las enaguas llenas de alambres y los apretados corsés no les permitían a las mujeres respirar bien y era corriente que se desmayaran, hecho que inmortalizó el Romanticismo dando realce a la noción de la mujer como ente débil e inerte en brazos del héroe romántico como único agente de aventuras y búsquedas trascendentales. Bajo la influencia de este movimiento artístico, las mujeres usaban polvos de arroz en el afán de lucir una tez pálida y acudían a las sombrillas para evitar el contacto directo de sus cuerpos con la luz del sol.

Casi todas las mujeres eran analfabetas, puesto que la educación se impartía exclusivamente a los hombres y sólo en los sectores más adinerados, algunas sabían leer y escribir — habilidades que les permitían usar la lectura como pasatiempo para el ocio burgués. La meta de todas ellas, sin distinción de clase social, era casarse y tener hijos para convertirse en Ángel del Hogar, en la madre y esposa que, por su 
inocencia innata y su ignorancia de los saberes y conflictos del Mundo de Afuera, debía salvaguardar la paz y la armonía en el hogar. A esta inocencia/ignorancia se agregaba la creencia de que, debido a la menstruación y a los cambios biológicos de la maternidad, las mujeres poseían una intuición que sustituía y complementaba la lógica y la razón —atributos que únicamente poseían los hombres. Además, se creía que, por su naturaleza intrínseca, tendían a una sentimentalidad que se expresaba a través de suspiros y copiosas lágrimas. A diferencia de los hombres poseedores de fuerza física y talento intelectual, la mujer era "puro corazón” y con su ternura y otras virtudes —entre ellas la obediencia y la sumisión- debía ser el apoyo espiritual de su esposo inserto en los avatares de la producción económica y el devenir histórico.

Su tesoro más preciado, según las prescripciones impuestas durante siglos por el patriarcado, era la virginidad —ese himen intacto que aseguraba al hombre la propiedad exclusiva de la mujer con quien se casaba. Y el hecho de que se casara no significaba que cruzara el umbral de la sexualidad plena. Por el contrario, mientras el hombre practicaba el adulterio como un símbolo más de su virilidad, la actividad sexual de la esposa se restringía al único objetivo de la reproducción biológica dentro de un paradigma en el cual el hombre era el agente activo y el sujeto del placer relegando a la mujer al rol de objeto pasivo y mero receptáculo de la gestación de los hijos que, según las creencias de la época, era promovida exclusivamente por los espermatozoides. ${ }^{1}$

\section{Desafíos estéticos de la escritura de mujer}

Cuerpos cercados por el armado metálico de las enaguas y las varillas que se incrustan en la cintura y parte del vientre. Conciencias/subjetividades acosadas por prescripciones que determinan lo que Es y Debe Ser una mujer. En el vasto imaginario cultural predomina una sola perspectiva masculina dentro de la economía de Lo Mismo que permea todos los sistemas y desde el púlpito y pedestal de una hegemonía patriarcal, el rol primario de la mujer como madre y esposa resulta ser el resorte y trampolín que la condena a ser el otro ausente de la historia oficial, de ese Afuera donde sólo a los hombres les está permitido ser sujetos agentes.

Dentro de una lógica de género que estructura la prolífera meta-narrativa acerca de la mujer, Fray Luis de León en La perfecta casada (1583) asevera: “. . por donde,

1 Las postulaciones de Aristóteles fueron confirmadas por Antonie van Leeuwenhoek en 1677 con el descubrimiento de los espermatozoides a través del microscopio y su afirmación de que cada uno de estos era un ser humano en miniatura y ya completamente formado, razón por la cual el vientre materno se consideraba un mero receptáculo que lo alimentaba. Sólo en 1826, Karl Ernst von Baer demuestra científicamente la existencia del óvulo en los mamíferos y en 1876, Oscar Hertwick explica que la fertilización se debe a la penetración del espermatozoide en un óvulo. 
así, a la mujer buena y honesta la naturaleza no la hizo para el estudio de las ciencias ni para los negocios sino para un solo oficio simple y doméstico, así les limitó el entender, y por consiguiente les tasó las palabras y las razones. . ." (200). Esta radical exclusión de las mujeres incluso en el lenguaje se eufemiza posteriormente dándole un carácter sublime en una estrategia de poder. Jean-Jacques Rousseau en Emilio (1762) define a Sophie como "el complemento del bello sexo" (363) en un hogar que denomina "el noble imperio de la mujer" (393), mientras Augusto Comte insiste en la veneración que se merecen las mujeres por ser: "Nacidas para amar y ser amadas, eximidas de los deberes de la vida práctica [y] libres en el sagrado retiro de sus hogares" (288).

¿Cuáles habrán sido los márgenes y excesos identitarios de esta Mujer Dicha por los hombres? Susan K. Cornillon señala: "En la cultura masculina, la noción de 'lo femenino' se expresa, se define y se percibe por el hombre como una condición de ser mujer mientras que, para la mujer, esta noción de 'lo femenino' es vista como una adición a la propia femineidad, como un status o meta que debe ser lograda" (113). La Mujer Dicha, a diferencia de la Mujer Diciéndose a Sí Misma, es una versión adulterada en una construcción cultural creada por la estructura patriarcal para obtener sus propios objetivos económicos y nacionales utilizando la familia heterosexual como núcleo básico. En una literatura decimonónica en la cual se emitían discursos e historias sobre la mujer y no en ella o por ella, las escritoras latinoamericanas enfrentaron el desafío de un campo intertextual masculino que, aparte de distorsionar la identidad femenina, estaba plagado de silencios y vacíos con respecto a las vivencias de la mujer. ¿Cómo entonces escribir subjetividades femeninas desde una perspectiva interior que carecía de un discurso y un repertorio simbólico propios? La única alternativa escritural era imitar los formatos masculinos introduciendo una diferencia genérica en el doblaje o repetición ahora emitida desde el sitio creativo de la mujer.

Como ha señalado Luce Irigaray, la exclusión social de la mujer conlleva una exclusión en la economía de la significación y, por lo tanto, atrapada en un lenguaje y en un tejido de construcciones culturales que no la representan, debe recurrir a la mímica y al uso de la máscara de una femineidad fabricada desde una perspectiva masculina. En un acto de agencia muy diferente al imitar modelos e ideologías de manera sumisa, la estrategia de la mímica es un recurso de resistencia dentro del mismo sistema y pone de manifiesto los silencios y mistificaciones de una noción de "lo femenino" que ha sido impuesta a través de diversos dispositivos de poder. Judith Butler destaca el carácter transgresivo de este tipo de imitación en el discurso mismo de Irigaray al comentar figuras canónicas de la tradición filosófica: "Se trata de hacer citas, no como una reiteración esclavizada del original, sino como una insubordinación que parece tomar lugar dentro de los mismos términos del 
original y que cuestiona el poder del origen que Platón reclama para sí mismo" (45). La práctica textual de la mímica habita el sistema imitado y al mismo tiempo, lo penetra, lo ocupa y lo desmantela.

Es más, la mímica es un discurso de doble articulación en el cual se entrelazan la inteligibilidad de la noción hegemónica de "lo femenino" y experiencias de la mujer que están fuera de la representación falogocéntrica ("El sistema simbólico las divide en dos. En ellas, la 'apariencia' permanece como algo externo y ajeno a lo natural. Socialmente, ellas permanecen amorfas, experimentando impulsos que están fuera de toda representación" (Irigaray 189).

Desde los estudios poscoloniales, Homi Bhabha observa esta doble articulación en el caso del colonizado quien imita la cultura del colonizador en una estrategia de apropiación para expresar su propia visión del poder y producir la legitimación del otro subalterno en un acto que desestabiliza los saberes normalizados y los poderes disciplinarios.

En la narrativa de la mujer latinoamericana, a través de la estética de la mímica, se añaden contratextos, márgenes y sub-textos que modifican el modelo original en un acto transgresivo que va desde la leve y estratégica reconfiguración a la emisión de discursos contestatarios que no sólo hacen una denuncia y desestabilizan las normas de la femineidad prescriptiva, sino que también elaboran un imaginario con respecto al cuerpo de mujer y su identidad desde una perspectiva femenina que cuestiona los presupuestos ontológicos y los paradigmas epistemológicos de los sistemas androcéntricos.

\section{La heroína romántica en las redes de la mímica}

El rechazo del movimiento romántico a los valores mercantilistas y el desarrollo de la ciudad moderna hizo de sus héroes, seres marginales en una sociedad utilitaria, entes que buscaban una trascendencia espiritual a través del amor que los guiaría a esa meta espiritual. En este proceso, la mujer amada estaba íntimamente ligada a la naturaleza y su inocencia semejaba la del Buen Salvaje por no estar contaminada aún por la civilización. Idealización de la mujer que excluyó su verdadera posición social. No obstante el carácter disidente del Romanticismo, la configuración de la heroína romántica (símbolo de la belleza, la espiritualidad y la pureza) es la proyección imaginaria de un sujeto masculino que la inmoviliza en su perfección y refuerza su lugar de un otro inmanente y carente de agencia al ser sólo el vehículo intermediario a través del cual el héroe como sujeto agente ascenderá a su objetivo trascendental.

A mediados del siglo XIX, la lucha por el acceso de la mujer a la educación puso de manifiesto una desigualdad genérica que ya no se justificaba plenamente 
a partir de una diferencia biológica innata. La voz aislada de Mary Wollstonecraft en Reivindicación de los derechos de la mujer (1792) tenía ahora una resonancia colectiva. En este libro declara: "Si la mujer es en general débil en cuerpo y entendimiento, se debe menos a su naturaleza que a su educación" (55-56). La desencialización de la debilidad como elemento natural innato era ahora una circunstancia histórica y, por lo tanto, modificable.

Dentro de este contexto, la modelización original de la heroína romántica desde una perspectiva androcéntrica, se moviliza, adquiere márgenes y pone en evidencia un devenir histórico impregnado por la violencia masculina.

Carlota, protagonista de Sab (1841) — primera novela escrita por una mujer latinoamericana- es la copia fiel de la heroína romántica en un texto visible que oculta a medias un sub-texto dentro de una estructura palimpséstica. La típica heroína con su tez de azucena es amada por el esclavo Sab en un amor imposible debido a las diferencias étnicas. Sin embargo, en los capítulos finales, surge otra Carlota: una mujer que es víctima de la femineidad prescriptiva y un matrimonio desdichado.

En una mirada retrospectiva, la historia visible del esclavo y su contenido abolicionista resulta ser un recurso estratégico de Gertrudis Gómez de Avellaneda para denunciar la situación de la mujer. ${ }^{2}$ La condición sufriente de Sab posee un reflejo homólogo en Carlota y ambos son víctimas de una esclavitud que va contra la armonía de la naturaleza como creación de Dios. Antes de suicidarse, Sab escribe una carta en la cual exclama: “¡Oh! ¡las mujeres! ¡Pobres y ciegas víctimas! Como los esclavos, ellas arrastran pacientemente su cadena y bajan la cabeza bajo el yugo de las leyes humanas. . El esclavo, al menos, puede cambiar de amo. . . pero la mujer, cuando levanta sus manos enflaquecidas y su frente ultrajada para pedir libertad, oye el monstruo de voz sepulcral que le grita: 'En la tumba”' (270-271).

Carlota es también el contrasello del Sujeto Romántico en una alteridad subalterna que no le permite ni la trascendencia espiritual ni un acto de resistencia. Se inicia así la presencia textual de una modalidad hermética de la existencia que será recurrente hasta mediados del siglo XX.

Apropiándose del folletín amoroso, Gómez de Avellaneda en Dos mujeres (1842) inscribe su posición no convencional acerca del adulterio, el amor, la masculinidad y la subjetividad femenina. Es más, traspasando las fronteras genéricas, caracteriza

2 Esta relación entre los esclavos y las mujeres blancas no es fortuita. La activa participación de ellas en los movimientos abolicionistas dio origen a los grupos organizados del primer movimiento feminista en Estados Unidos e Inglaterra (ver, por ejemplo, C. Midgley. Women Against Slavery: The British Campaigns 1780-1870. Londres: Routledge, 1992). Un caso similar ocurrió en el siglo XX. La participación de las mujeres en la lucha por los derechos civiles de los afro-americanos en USA promovió un activismo político que dio origen a los nuevos movimientos feministas de la década de los setenta. 
a Catalina como un héroe romántico, añadiendo a la sensibilidad y búsqueda trascendental una marginalidad en la esfera de la subordinación de la mujer. Extendiendo el fatum romántico, Catalina es condenada por poseer inteligencia, saber y talento artístico considerados como atributos exclusivos de los hombres.

Para la femineidad prescriptiva, ella es una mujer que desborda los límites, un excedente de los encasillamientos genéricos. Después de reflexionar sobre las diversas actividades que realizan los hombres, exclama: "Pero ¡la pobre mujer, sin más que un destino en el mundo! ¿qué hará, qué será cuando no puede ser lo que únicamente le está permitido?" (94). En el espacio hermético de un cuarto de su casa, Catalina se suicida como el único acto que una mujer de su época podía libremente elegir.

Subjetividades dolientes, mujeres que deambulan entre cadáveres y ruinas, vestidos de novia que se transforman en largos sudarios. Figuras fantasmales, atavíos fúnebres. La heroína romántica europea que sufre por amor en una elegante recámara, deviene en un personaje patético en la narrativa de Juana Manuela Gorriti y el espacio burgués es sustituido por la nación argentina durante la dictadura de Juan Manuel de Rosas (1835-1852).

Desde los márgenes de la historia oficial (la historia de los hombres), Gorriti configura a la heroína romántica en el contexto de las vivencias de aquellas mujeres que, bajo la violencia de la dictadura, han sufrido la muerte de un ser querido o la violencia en la casa, ya sea por ruido de armas, invasión o destrucción bajo la experiencia que Homi Bhabha ha denominado lo "unhomely". 3

En Elpozo de Yocci (1863), Gorriti se refiere al "barro de Adán” (185), a la violencia como un impulso inherente a la naturaleza de los hombres con sus orígenes en el limo inicial de la creación bíblica en una escisión genérica en la cual la mujer, en su función de dadora de vida, se caracteriza por su generosidad y abnegación dentro de una esfera guiada por lo que, en los términos contemporáneos de Marcel Mauss, corresponde a la economía del Don en contraposición a la economía de lo Propio gobernada por la ambición, el espíritu competitivo y la violencia.

Exacerbando las virtudes femeninas en el imaginario patriarcal, Gorriti elabora a sus personajes femeninos como víctimas, bienhechoras o agentes de fuerzas mágicas que, de manera tangencial al devenir histórico, se desplazan en el ámbito de

3 Extendiendo la noción freudiana de "lo inquietante" (the "uncanny") como aquello que interrumpe lo conocido y lo familiar creando extrañeza, miedo o terror, Bhabha define lo "unhomely" como aquellos elementos del Afuera que irrumpen e invaden el espacio íntimo del hogar diluyendo los límites establecidos y produciendo la inquietante y desorientadora sensación de que lo público y lo privado se han fusionado ("The World and the Home", Dangerous Liaisons ed. por A. McClintock, A. Mutty y E. Shohat. Minneapolis: University of Minnesota Press, 1997, 445-455). 
lo intuitivo, lo premonitorio y lo sobrenatural. En una nación argentina dominada por la violencia de la dictadura, ellas son samaritanas, oráculos y madres dolorosas en medio del conflicto metafísico entre el Bien y el Mal elaborado a partir de la antítesis romántica. Así, en los relatos de Sueños y realidades (1865), predomina el tema de la maternidad tronchada, ya sea por el asesinato de un hijo o una hija en un acto de parricidio, la inmolación de una novia o la muerte del amado. La violencia masculina crea una oposición genérica entre víctima y victimario y a modo de epílogo, una mujer como alma en pena, loca o peregrina deambula entre los muertos y las ruinas. Estas figuras patéticas ponen de manifiesto la violencia masculina como una fuerza que no solo destruye el orden natural que la mujer sustenta con su fertilidad, sino que también afecta a toda la nación.

A diferencia de los miembros de la Generación de 1837, quienes poseían una sólida plataforma ideológica de corte liberal, Gorriti en su lugar subalterno de mujer no educada en instituciones académicas postula el futuro de la nación regido por valores cristianos que menoscabarán el poder exclusivo de los hombres bajo la intervención de la mujer, hecho que hace imperativo su acceso a la educación. En un artículo publicado en su revista Alborada, de agosto de 1877, la autora afirma que los pueblos más firmes son "aquellos en que la mujer por su instrucción y moralidad los enseña a ser más justos y sobrios" (9-12-1877, $\left.\mathrm{N}^{\circ} 1,25\right)$.

Compartiendo los principios del feminismo doméstico, Gorriti le atribuye a la mujer, una función social como madre republicana, resguardadora de la moral cuyas virtudes producirán una regeneración ética de la nación. Su función de madre pasará entonces del ámbito privado a un bien público.

Durante los años veinte, la moda produjo un cambio drástico en la silueta de la mujer. La Primera Guerra Mundial (1914-1918) forzó al reclutamiento de miles de soldados y muchas mujeres debieron entrar al campo laboral para reemplazarlos, hecho que demostró que poseían otras habilidades aparte de las domésticas.

Se puso de moda entonces un vestuario cómodo y sencillo que permitía trabajar de manera rápida y eficiente. Melenas cortas y vestidos holgados en línea vertical cancelaron el corsé mientras los zapatos eran de taco ancho para permitir un andar ágil. Las faldas cortas le dieron, por primera vez, un protagonismo a las piernas que se lucían bajo finas medias de seda. Los rostros también experimentaron un cambio notable gracias a la genialidad de Max Factor —un judío que emigró de Rusia a los Estados Unidos e inventó el nuevo maquillaje de las artistas de cine. En 1916, abrió una tienda para vender todos sus productos (bases faciales, cosméticos para los ojos, lápices labiales, esmaltes de uñas) y así se produjo la llamada Democratización de la Belleza. 
Terminada la guerra, se inició en Estados Unidos, la Segunda Revolución Industrial basada en el desarrollo de la tecnología. La difusión de la electricidad, el cine, la radio, el teléfono, el automóvil y el transporte aéreo transformaron el silencioso mundo en un espacio de voces, imágenes y ruido de motores. Dentro de este nuevo contexto, se amplió el campo laboral de las mujeres, tanto en la creciente industria como en su rol de operadoras telefónicas, secretarias y profesoras.

No obstante la figura cinematográfica de la Flapper (nueva vampiresa de atavío sofisticado, rostro maquillado y cigarro en una larga boquilla) era la imagen de la frivolidad y una independencia que suponía una libertad sexual, la mayoría de las mujeres seguían regidas por la femineidad prescriptiva.

Aunque algunas trabajaban, dentro de la casa y en la nación misma seguía predominando la discriminación genérica. La larga lucha por el derecho a voto que engendró demostraciones callejeras, cárcel y huelgas de hambre en Inglaterra y Estados Unidos logró su objetivo en 1918 y 1920 respectivamente. En Latinoamérica, el proceso fue aún más largo: en Uruguay, la mujer obtuvo su derecho a voto en 1927 mientras que en Colombia sólo le fue concedido en 1957.

Como en el caso del acceso a la educación, la participación política de la mujer tampoco hizo posible la igualdad de género porque en las redes rizomáticas de los dispositivos patriarcales perduraron las preconcepciones acerca del hombre y la mujer.

\section{Cuerpo, subjetividad y el valor identitario de la sexualidad}

Hacia los años veinte, las escritoras habían logrado una cierta autonomía escritural y una conciencia de su especificidad genérica que les permitió un cuestionamiento tanto de la femineidad normativa como de los soportes de una epistemología y orden simbólico de carácter falogocéntrico.

En nuestra cultura, moda y cosméticos son sinónimo de la femineidad como categoría configurada dentro del campo semántico de lo falso y superficial, verdadero emblema de la "esencia" inesencial de la mujer. Sin embargo, como señala Jean Baudrillard, tras el adorno yace un importante elemento transgresor: "La mujer no es otra cosa que apariencia. Y es lo femenino como apariencia lo que socava a la profundidad masculina. No se trata simplemente de que lo femenino como superficie se oponga a lo masculino como profundidad, sino que lo femenino es la indistinción entre superficie y profundidad. O la indiferencia con respecto a las categorías de lo auténtico y lo superficial. Lo masculino, por el contrario, posee sólidos poderes de discriminación y criterios absolutos para pronunciar la verdad" (10-11). Cosméticos, ropa y adorno son la mascarada que desenmascara la supuesta solidez y verdad de las nociones abstractas del Ser y la Esencia. 
Los rituales de la moda y los cosméticos son en Ifigenia. Diario de una señorita que escribia porque se fastidiaba (1924) de Teresa de la Parra una apertura significativa con respecto a la representación de la mujer y un imaginario desde una perspectiva femenina. El formato del diario íntimo permite a María Eugenia un tono y contenido que escapa a la censura y la autoridad masculina, es más, al transcribir las voces de la tía, la abuela y César Leal, estas adquieren una cualidad paródica. El cuarto donde escribe es así un margen transgresivo de la casa y morada de lo excéntrico, el espacio de una cotidianeidad de la mujer que, según Virginia Woolf, correspondía a lo tachado en la literatura de los hombres.

Y es dentro de lo cotidiano donde la ropa y los cosméticos junto con la escritura constituyen los resquicios ocultos a través de los cuales la protagonista logra residualmente constituirse en sujeto. El espejo, lejos de crear fracturas o distancias entre un aquí y un allá, en teoría lacaniana, envía imágenes que la constituyen otorgándole un sentido de identidad y una autonomía con respecto a la mirada de los otros porque es su propia mirada la que la constituye cancelando su función subalterna de Objeto de Contemplación y Objeto del Deseo.

María Eugenia, al mirar su cuerpo, se sumerge en una sensualidad fuera de una economía masculina y la multiplicidad y fluidez de su sexualidad evade todo falomorfismo. Así, como contratexto de una sexualidad que tiene como meta la penetración fálica, ella extiende sobre la cama su ajuar de novia, se despoja del kimono y se envuelve desnuda en la caricia de la seda. La ropa y los cosméticos, aparte de ser fuente de placer en una jouissance fuera de los parámetros masculinos, son agentes de rituales gratificantes y vivencias narcisistas (Hanson, 231-232) en una creatividad femenina independiente de los códigos y estereotipos impuestos, como demostrará Frieda Khalo en sus auto-retratos.

Sin otra alternativa que casarse, María Eugenia claudica al Orden en un acto de inmolación que la hace sentir como Ifigenia al ser sacrificada por su padre. Junto con cruzar el umbral de la femineidad performativa con sus códigos estrictos y detallados guiones, cesa la escritura de su diario y sus últimas palabras son: "Esta blanca hoja cuadrada tiene el tamaño y la blancura de esas pobres lápidas de mármol. . . aquí lo que escribo. . . es como escribir yo misma mi epitafio" (316). La claudicación engendra el fin de la escritura indicando que la existencia de María Eugenia ahora será una hoja en blanco.

En la narrativa de María Luisa Bombal, la sexualidad de la mujer se inscribe, por primera vez en la narrativa latinoamericana, en un discurso e imaginario que la hace visible e inteligible desde una perspectiva femenina. En la cultura de occidente, la sexualidad de la mujer ha sido analizada a partir de parámetros falogocéntri- 
cos que la distorsionan y cancelan. ${ }^{4} \mathrm{El}$ sistema patriarcal regido por una economía escópica que favorece lo visible le ha otorgado prioridad al falo mientras la vagina representa el negativo de lo morfológicamente designable, sinónimo en la teoría de Freud, de la carencia, la atrofia y la castración. Es más, desde los orígenes de nuestra cultura, solo el hombre ha sido sujeto del Deseo, como afirma Michel Foucault: "La ética griega del placer está ligada a una sociedad viril, a la no-simetría, a la exclusión del otro, a la obsesión de la penetración y a una especie de amenaza de verse desposeído de la propia energía” (190).

En La última niebla (1935), "el surco vacío en el lecho” (Bombal 50) es la huella de la ausencia de la sexualidad en una metonimia que se extiende a la turbia inquietud, el silencio, la muchacha muerta, la niebla y el soplo frío de un pájaro que pasa rozándola en un augurio de muerte, de la negación del placer sexual como signo de vida. "Yo existo, yo existo —exclama la protagonista sin nombre-. La felicidad no es más que tener un cuerpo joven y esbelto y ágil" (51). Desde la perspectiva de Merleau-Ponty, quien anula el binarismo entre Cuerpo y Mente, esta escena corresponde a una conciencia encarnada, a un cuerpo con la capacidad de percibir y vivir en el mundo en una continuidad recíproca, en un cuerpo que es existencia y condición de existencia.

En esta primera etapa del Deseo, la subjetividad femenina sólo intuye una carencia y un anhelo. Será Regina, como agente mediadora, quien hará visible el impulso libidinal y la posibilidad de significarse a través del cuerpo (Gutiérrez Mouat 105). Después de presenciar la pasión entre Regina y su amante, la protagonista se interna en el bosque donde un rayo de sol rompe la niebla, "hurga la tierra y se desprenden de ella aromas profundos y mojados" (Bombal 52). Se apoya contra el tronco de un árbol deseando estrechar "un cuerpo ardiente y rodar con él, enlazada, por una pendiente sin fin" (52). Las connotaciones sexuales de la tierra húmeda penetrada por el rayo de sol y el símbolo viril del árbol erecto coinciden con los arquetipos hegemónicos de "lo femenino" y "lo masculino" a través de un lenguaje poético que, en todo el texto, eufemiza y al mismo tiempo, legitima el Deseo de mujer. ${ }^{5}$

Se inicia así un proceso de subjetivación en el cual la protagonista, a través de su cuerpo, se constituye en sujeto. En la fuga y evasión hacia el espacio natural, se produce la desculturización cuando se sumerge desnuda en el estanque liberán-

\footnotetext{
4 Basta recordar que la palabra "vagina" fue usada científicamente por primera vez por John Vesling (1598-1649) para describir aquella parte del cuerpo femenino que envuelve el falo durante el coito. Etimológicamente, esta palabra se asocia con "vaina" — receptáculo botánico de las semillas que, como tal, es un envoltorio pasivo.

5 Para un análisis detallado de este aspecto, consultar mi libro Mujer, cuerpo y escritura en la narrativa de María Luisa Bombal.
} 
dose de las inscripciones culturales. "No me sabía tan blanca y hermosa" (53) se dice en un descubrimiento del cuerpo propio y del placer sexual producido por el contacto con el agua y las plantas acuáticas. En una difusión erótica que cancela la localización nuclear de la penetración fálica, se da una economía libidinal femenina (Cixous) en la cual el agua acaricia y penetra todo el cuerpo; es más, el agua, como elemento primigenio, representa lo anterior a las formas y a los procesos culturales que organizan y dominan a la naturaleza.

En un espacio igualmente desculturizado, se produce el encuentro con el amante real, soñado o imaginado. La fuente de agua y la vegetación de la plaza, la hacen sentir "en pleno campo" (57) y la casa envejecida con su jardín abandonado y cretonas descoloridas es el contratexto de todo progreso civilizatorio. El amante bajo la luz del farol oscurecido por la niebla aparece como una sombra de rasgos difusos y carece de todo signo cultural, incluido el lenguaje ya que nunca habla. Él es sólo un cuerpo que la guía, un cuerpo desnudo que es eco sonoro del corazón, sangre que corre por las venas, músculos y respiración en una expresión primaria de vida ("Entre mis brazos, toda una vida física, con su fragilidad y misterio, bulle y se precipita" (59)).

Dentro de este contexto, el orgasmo sexual es trascendido y legitimado como sinónimo de vida, de esa energía y misterio que la cultura trata, desde sus inicios, de descifrar con el propósito pragmático de utilizarla. En este ámbito de lo natural que remite a lo primigenio y lo cósmico, la protagonista cuenta: "Entonces él se inclina sobre mí y rodamos enlazados al hueco del lecho. Su cuerpo me cubre como una grande ola hirviente, me acaricia, me quema, me penetra, me envuelve, me arrastra desfallecida. A mi garganta sube algo así como un sollozo, y no sé por qué empiezo a quejarme, y no sé por qué me es dulce quejarme, y dulce a mi cuerpo el cansancio infligido por la preciosa carga que pesa entre mis muslos" (59).

Aquí, como en la escena del estanque, el verbo "penetrar" tiene un carácter fluido y difuso que se contrapone al evento de la penetración fálica en el discurso de la sexualidad masculina. Para la subjetividad de la protagonista en una jouissance fuera de los parámetros masculinos, el cuerpo del amante es una ola que la envuelve y arrastra, una preciosa carga que pesa entre sus muslos en una des-subjetivación que lo despoja de las inscripciones culturales atribuidas a los hombres en una posición de sujeto.

Dentro de los códigos de la masculinidad, la actividad sexual es un atributo ontológico puesto que se considera un requisito esencial para "ser hombre" tan importante como la capacidad para dominar la naturaleza y dirigir a otros hombres en el caso del machismo cuyos orígenes se dan en nuestro continente con la 
Conquista de América. ${ }^{6}$ Yendo contra los atributos de la inocencia y la pureza en la femineidad prescriptiva, el discurso de la sexualidad en La última niebla plantea la experiencia sexual y la satisfacción del Deseo como una razón de Ser, como el vehículo que provee a la subjetividad femenina, un sentido y un significado para su existencia.

Sin embargo, la historia se resuelve en la derrota, en la claudicación al Orden simbolizado por la niebla ahora en una inmovilidad definitiva. Atribuyendo su situación a "un destino implacable" (79) y no a una circunstancia histórica susceptible de ser modificada, la protagonista pone fin a su aventura interior que le ha permitido procesos de subjetivación y sigue a Daniel ("Lo sigo para vivir correctamente, para morir correctamente algún día" (79)).

Si la mímica en los textos del siglo XIX correspondía a una imitación que agregaba márgenes e inversiones, en la narrativa del siglo XX, la mímica se da en la esfera ontológica y epistemológica. Se producen así procesos de reapropiación en los cuales se utilizan, de manera estratégica, las nociones hegemónicas de "lo femenino". En el caso de Bombal, la ecuación Mujer-Naturaleza, Hombre-Cultura se re-dice para negar la supuesta "dialéctica entre los sexos" ("Islas nuevas" 1939), para contradecir la visión cristiana de la muerte inscribiendo "lo femenino" en la Materia (La amortajada 1938) y establecer una escisión genérica en el Saber postulando otros parámetros del conocimiento, como se hace evidente en sus crónicas poéticas.

Armonía Somers en La mujer desnuda (1950) hace algo semejante desdiciendo el mito bíblico para establecer otro origen y otra genealogía de la mujer. En el fotomontaje "No Veo la (Mujer) Oculta en el Bosque" (1929), René Magritte presenta en el centro una mujer desnuda en grácil e inofensiva pose de estatua clásica enmarcada por las fotos de varios artistas de la vanguardia que mantienen los ojos cerrados. Este marco representa el cerco cultural creado por la imaginación masculina con respecto a la mujer moldeada y esculpida como Objeto del Deseo y el Placer mientras "el no poder ver" es la imposibilidad de ver/conocer a la mujer en una complejidad enigmática. En La mujer desnuda, Rebeca Linke es también una mujer oculta en el bosque, pero contradiciendo el pudor y la sumisión de la $\mathrm{Mu}$ jer-Dicha desde una perspectiva masculina, ella es Sujeto del Deseo que subvierte el imaginario de "lo femenino" con Eva pecadora como la mujer que da inicio a un prolífero repertorio simbólico de corte marianista o misógino.

6 Los conquistadores españoles llegaron a América con tres modelos básicos de la masculinidad: los santos en hagiografías que eran muy populares en la época, los héroes de las novelas de caballería y Don Juan con sus numerosas conquistas amorosas. El nuevo entorno americano dio origen a una noción de "lo masculino" definido como la capacidad para dominar la naturaleza, ser líder de otros hombres y poseer varias mujeres. 
Rebeca es una mujer de treinta años sometida al Deber-Ser de las prescripciones genéricas y un día decide tomar un tren y viajar hasta una casa abandonada cerca de un bosque. Al entrar a la casa, se despoja del abrigo, queda desnuda y siente que ha retornado "a la matriz primaria" (17) fuera del tiempo, la memoria y los guiones performativos impuestos a la mujer. En una escena que no puede calificarse como fantástica, puesto que el suceso no oscila ambiguamente en la duda, una daga "se desplaza atraída por las puntas de unos dedos" (18), penetra el cuello de Rebeca y cercena su cabeza. Dentro de esta nueva visión de "lo real" (Olivera-Williams), se inserta una nueva subjetividad liberada e inscrita en otra modalidad del Ser fuera del sitio ontológico asignado. En este contexto, la decapitación anula los valores masculinos reforzados por Perseo en el mito. La figura horrenda de la cabeza de Medusa como amenaza de castración, según Freud, es aquí "pesado fruto" y "amapola en sazón de semilla" (19). ${ }^{7}$ Dos imágenes que pertenecen al campo semántico de lo natural y grávido en una versión femenina del mito y que, como tal, omite toda dimensión fálica.

Fuera del tiempo teleológico tan caro al falogocentrismo, Rebeca toma la cabeza mientras esta experimenta una significativa metamorfosis a través de la cual adquiere "una personalidad retadora" (20) y se la vuelve a poner dando inicio a una existencia propia ("Y fue desde aquel instante. . . que comenzó la noche de la mujer, su primera noche poseída” (22)). En un Sí Misma pleno, vive una nueva identidad ubicada en los orígenes anteriores al pecado de Eva. Identidad edénica fundamentada en el cuerpo desnudo que es también conciencia en una indiferenciación anterior a las construcciones culturales. Se interna entonces en el bosque en un rondar no regido por la linealidad de una meta, como es corriente en el imaginario androcéntrico. Sin hazañas heroicas ni iniciaciones trascendentales, ella es una nueva Gradiva que camina entre el bosque, el río y la aldea - sitio de discriminaciones hacia la mujer sustentadas por la religión católica, el machismo y la asignación patriarcal de roles primarios.

La protagonista es ahora habitada por una genealogía de mujeres que desobedecieron, que fueron libres sexualmente e incluso se insertaron en el ámbito político: ella es Eva antes del Pecado Original, Judith, Semíramis, María Magdalena y Frené. Es también la portadora de la sexualidad primigenia y gestora de vida que despierta

7 En 1922, Sigmund Freud escribió un breve texto titulado "La cabeza de Medusa" que sólo fue publicado en 1940. En su interpretación sicoanalítica del mito, Freud postula que la cabeza de Medusa es un símbolo de la castración y produce el mismo horror que siente el niño al ver, por primera vez, los órganos genitales femeninos. Esta sensación es aminorada, sin embargo, por la cabellera de Medusa entrelazada a serpientes que semejan falos erectos y producen en quien las ve una rigidez semejante a la erección del pene y su poder de conjuración contra las fuerzas malignas. Razón por la cual afirma: "Mostrar el pene (o cualquier otro de sus sustitutos) es decir: 'No te temo. Te desafío. Yo tengo un pene'. Aquí entonces tenemos otro modo de intimidar al Espíritu del Mal" (213). 
en los hombres de la aldea un Deseo también primigenio y no intervenido por fabricaciones culturales. Aprisionados por un Orden que se ratifica a través de mitos y leyendas, para ellos la mujer desnuda se convierte en una obsesión, en la "hembra maldita" (48) que debe ser perseguida y eliminada como antaño las brujas. ${ }^{8}$

La itinerancia de la mujer desnuda se presenta como una búsqueda fuera del ámbito de la razón y un objetivo concreto, “algo que no parecía contar con nombre entre las cosas previsibles y ordenadas como aparecen en los diccionarios" (86). La omisión de la meta teleológica, de la designación racional, del tiempo y la memoria apuntan hacia una cancelación epistémica que refuerza lo primigenio como trazo ontológico.

Es en este ámbito donde se da el encuentro con Juan en un presente que junto con anular todo pasado y futuro, postula la fusión de lo femenino y lo masculino en una relación de amor/sexo más allá del lenguaje ("El sexo con los verbos ya sin conjugar" (95)) en la cual se anula la distinción binaria entre el hombre como agente activo y la mujer como Objeto pasivo del Deseo. Es más, la agresividad masculina es sustituida por la pureza y la paz, por una dulzura que se define como femenina ("Qué femenino y suave le parecía él en aquel sitio" (90)). Ambos revierten, por lo tanto, a la pareja primordial en un espacio edénico que ha cancelado los códigos y guiones de género.

Sin embargo, este amor/sexo paradisíaco está condenado a la derrota bajo el ataque de la muchedumbre que contradictoriamente odia y desea a la mujer desnuda. Juan muere a golpes, la iglesia arde y ella huye al bosque. Antes de llegar al río, se encuentra con el caballo que antes había dejado en libertad y este atraviesa el río sin penetrar en el agua. La espera en la otra orilla y como símbolo de la imposibilidad de la mujer de liberarse de un Orden que ha anulado su Ser cubriéndola de regulaciones, prejuicios y mistificaciones, ella cae al río que se convierte en "el féretro deslizante del agua" (123) y se incorpora al ámbito primordial, hecho que sólo es posible después de la muerte.

8 La persecución y quema de "brujas" entre el siglo XIII y el siglo XVII respondía al temor hacia las mujeres tanto a nivel sexual como en la esfera del conocimiento y la evolución del capitalismo. (Con respecto a este último factor, consultar el libro de Sylvia Federici titulado Caliban and the Witch: Women, the Body, and Primitive Accumulation. Nueva York: Autonomedia, 2014). Como transgresora del rol de madre y esposa, la "bruja" adquirió los rasgos siniestros de comer niños recién nacidos, de montar una escoba y volar en vez de barrer, y de hechizar a los hombres con pócimas de yerbas, sudor y sangre menstrual ocultas en comidas y bebidas. Tras estas imágenes, yacía el temor a una sub-cultura femenina en la cual se desarrollaba el conocimiento de parteras, curanderas y restauradoras de virgos más las estrategias de sobrevivencia que permitían a la mujer obtener un marido que la mantuviera y "asimplar" o "amansar" al que la golpeaba y quitar su potencia sexual si practicaba el adulterio. 
Subjetividades femeninas: de la mímica subversiva a los discursos contestatarios

Lucía Guerra-Cunningham

La modificación y apropiación de la figura bíblica de Eva en una identidad primigenia y sin pecado alguno, establece una genealogía otra que intenta cancelar los mitos y prejuicios tanto a nivel socio-cultural como en la esfera ontológica de la identidad femenina.

La estrategia de la mímica subversiva, la inscripción de la sexualidad femenina y el cuestionamiento de paradigmas filosóficos desde una perspectiva de mujer Diciéndose a Sí Misma se perfilan como hitos de una genealogía de la escritura en un contexto cultural donde aún la Palabra de Mujer es una voz subalterna. 
CARTOGRAFíAS E IMAGINARIOS DE LA LITERATURA CHILENA: ESPACIOS, TEMPORALIDADES Y SUJETOS

\section{Obras citadas}

Baudrillard, Jean. Seduction. Nueva York: St. Martins Press, 1990.

Bhabha, Homi K. The Location of Culture. Nueva York: Routledge, 1994.

. "The World and the Home", Dangerous Liaison. Eds. A. McClintock, A. Mufty

y E. Shohat. Minneapolis: University of Minnesota Press, 1997. 445-455.

Bombal, María Luisa. Obras Completas recopiladas por Lucía Guerra. Santiago: Editorial Zig-Zag, 2010.

Butler, Judith. Bodies That Matter. On the Discursive Limits of Sex. Nueva York: Routledge, 1993.

Cixous, Hélene. La risa de la Medusa. Ensayos sobre la escritura. $\quad$ B a r c e l o n a : Anthropos, 1995.

Comte, Auguste. General View of Positivism compilado por J.H. Bridges.

Stanford: University of Stanford Pres, s/f.

Cornillon, Susan K. “The Fiction of Fiction”. Images of Women in Fiction: Feminist Perspectives. Bowling Green, Ohio: Bowling Green University Popular Press, 1972.

Federici, Sylvia. Caliban and the Witch: Women, the Body, and Primitive Accumulation. Nueva York: Autonomedia, 2014.

Foucault, Michel. "El sexo como moral", entrevista incluida en Saber y verdad. Madrid: La Piqueta, 1985. 188-195.

Freud, Sigmund. "Meduse's Head". Sexuality and the Psychology of Love ed. por P. Rieff.

Nueva York: MacMillan Publishing Co., Inc., 1963. 212-213.

Gómez de Avellaneda, Gertrudis. Dos mujeres. Obras de la Avellaneda, tomo V. La Habana: Imprenta de Aurelio Miranda, 1914.

. Sab. Madrid: Ediciones Cátedra, 1997.

Gorriti, Juana Manuela. "La educación de la mujer". La Alborada, 9-12- 1877, No 1, 22-29.

- Elpozo de Yocci. Buenos Aires: Imprenta de la Universidad, 1929.

. Sueños y realidades. Buenos Aires: Biblioteca de la Nación, 1909.

Guerra, Lucía. Mujer, cuerpo y escritura en la narrativa de María Luisa Bombal. Santiago: Ediciones UC, 2012.

Gutiérrez Mouat, Ricardo. "Construcción y represión del deseo en las novelas de María Luisa Bombal”. María Luisa Bombal: Apreciaciones críticas. Eds. M.Agosín, E. Gascón-Vera y J. Renjillian-Burgy. Tempe, Arizona: Bilingual Press/Editorial 
Bilingüe, 1987. 102-110.

Hanson, Karen. "Dressing Down Dressing Up: The Philosophic Fear of Fashion”. Aesthetics in Feminist Perspective. Eds. H. Hein y C. Korsmeyer. Bloomington: Indiana University Press, 1993. 229- 241.

Irigaray, Luce. This Sex Which Is Not One. Ithaca: Cornell University Press, 1985.

León, Fray Luis de. La perfecta casada. Barcelona: Montaner y Simón Editores, 1898.

Mauss, Marcel. The Gift: Forms and Functions of Exchange in Archaic Societies. Londres: Cohen \& West Ltd., 1976.

Merleau-Ponty, Maurice. Phenomenology of Perception. Londres: Routledge \& Kegan Paul, 1962.

Olivera-Williams, María Rosa. "La mujer desnuda como manifestación de la narrativa imaginaria". Armonía Somers, papeles críticos. Ed. Por Rómulo Cosse. Montevideo: Linardi y Risso, 1990. 159-171.

Parra, Teresa de la. Obras completas. Caracas: Editorial Ayacucho, 1982.

Rousseau, Jean-Jacques. Emilio or On Education. Nueva York: Basic Books, Inc. Publishers, 1978.

Somers, Armonía. La mujer desnuda. Buenos Aires: El Cuenco de Plata, 2009.

Wollstonecraft, Mary. A Vindication of the Rights of Woman. Nueva York: Source Book Press, 1971.

Woolf, Virginia. A Room of One's Own. Nueva York: Harcourt, Brace, Jovanovich, 1957. 